\title{
HUBUNGAN INTENSITAS PEMANFAATAN GADGET DENGAN PRESTASI BELAJAR SISWA KELAS V SEKOLAH DASAR
}

\author{
Maya Ferdiana Rozalia \\ SDN Tulusrejo 2 \\ e-mail: mayaferdiana94@gmail.com
}

\begin{abstract}
The purpose of this research is (1) describe intensity of gadget utilization; (2) describe student learning achievement; (3) find relationship between intensity of gadget utilization with student learning achievement. This research used correlational quantitative approach. This research result is: ;(1) intensity of gadget utilization (X) that in "medium" category according to students was 144 students with percentage $67 \% ;(2)$ in the variable of student learning achievement (Y), respondents with "enough" category was 153 students with percentage $71 \%$; (3) from data processing of this research result that been analyzed with error level $5 \%$ known that $r_{\text {calculation }}$ was -0.033 and $r_{\text {table }} 0.133$, hypothesis testing in this research stated that $\mathrm{h} 0$ accepted. Conclusion from this research could be stated that there was negative and insignificant relationship between intensity of gadget utilization and student learning achievement.
\end{abstract}

Keywords: Intensity, Gadget Utilization, Learning Achievement, Elemantary School

\begin{abstract}
Abstrak: Tujuan penelitian ini yaitu: (1) mendeskripsikan intensitas pemanfaatan gadget 2) mendeskripsikan prestasi belajar siswa; (3) menemukan hubungan intensitas pemanfaatan gadget dengan prestasi belajar siswa. Penelitian ini menggunakan rancangan kuantitatif korelasional. Hasil penelitian adalah: (1) intensitas pemanfaatan gadget (X) pada kategori "sedang", sebanyak 144 siswa dengan presentase $67 \%$;(2) Variabel prestasi belajar siswa (Y), responden termasuk dalam kategori "cukup", sebesar 153 siswa dengan presentase $71 \%$; (3) uji korelasi product moment yang telah dilakukan dengan tingkat kesalahan $5 \%$ diketahui $\mathrm{r}_{\text {hitung }}$ sebesar -0,033 dan $r_{\text {tabel }}$ sebesar 0,133 , pengujian hipotesis dalam penelitian ini menyatakan bahwa $h_{0}$ diterima. Kesimpulan penelitian dapat dinyatakan bahwa terdapat hubungan negatif yang tidak signifikan antara intensitas pemanfaatan gadget dengan prestasi belajar siswa.
\end{abstract}

Kata kunci: Intensitas, Pemanfaatan Gadget, Prestasi Belajar, Sekolah Dasar

\section{PENDAHULUAN}

Teknologi yang berkembang saat ini salah satunya yaitu gadget. Gadget digunakan oleh kalangan muda diantaranya siswa di usia sekolah dasar hingga dewasa. Penggunaan gadget berbeda pada anak usia sekolah dasar, berbeda dengan remaja dan orang dewasa. Anak usia sekolah dasar menggunakan gadegt cenderung sebagai hiburan. Berdasarkan observasi pada pelaksnaan Kajian Praktek Lapangan (KPL) ditemukan sejumlah siswa Sekolah Dasar membawa gadget namu tidak digunakan di saat pelajaran berlangsung. Namun ketika siswa tersebut pulang sekolah, gadget tersebut digunakan dan mereka tidak langusng pulang kerumah masing-masing. Salah satu gadget yang mereka gunakan yaitu berupa smartphone.

Salah satu teknologi canggih pada masa kini yaitu berupa alat komunikasi elektronik di antaranya yaitu Handphone, Laptop, camera , Tablet dan lain-lain. Teknologi yang berkembang pesat pada saat ini yaitu gadget. Gadget yang memiliki fungsi khusus di antaranya yaitu smartphone, I Phone dan blackberry. Berbagai aplikasi media sosial telah tersedia di dalam gadget. Sehingga telah banyak siswa Sekolah Dasar yang menyalahgunakan aplikasi tersebut yang berdampak negatif bagi nilai akademik mereka (Manumpil,2015:1).

Handphone yang dapat terhubung dengan layanan internet akan membantu siswa menemukan informasi yang dapat menopang pengetahuannya di sekolah. Namun, pada kenyataannya sangat sedikit pelajar yang memanfaatkan pada sisi ini, handphone yang mereka miliki umumnya digunakan untuk sms, main game, mendengarkan musik, menonton tayangan audio-visual, mengakses facebook, memfungsikan handphone bukan untuk fungsinya, dll. Selanjutnya, ini akan berdampak terhadap prestasi belajarnya di sekolah (Nikmah, 2013:2). Pengguna gagdet di Indonesia tidak hanya oleh kalangan dewasa, namun siswa sekolah dasar pun sudah pandai dalam menggunakan gadget. 
Orang tua memberikan gadget kepada anak karena mereka berpikir bahwa gadget mudah digunakan untuk belajar membaca, menulis, berhitung dan sebagainya. Banyak aplikasi-aplikasi edukatif bahkan permainan edukatif yang bisa membuat anak semakin pintar. Gadget juga digunakan agar anak tidak sering keluar rumah. Anak dapat mengenal huruf dan bilangan serta keterampilan mengetik dapat membantu anak yang lemah dalam motorik halus untuk meningkatkan koordinasi antara tangan dan mata. Mereka dapat menghasilkan karya yang dapat dibaca dan ditulis yang membanggakan bagi orang tua. Pembelajaran komputer dapat dimanfaatkan pada anak yang membutuhkan pendekatan kinestetik. Bagi anak yang memiliki kelemahan pada memori pendengarannya, dapat menggunakan permainan mengeja. Sehingga mereka akan terdorong untuk belajar (Orange dan O'Flynn, 2007:20).

Banyak ditemui siswa yang tidak mengerjakan tugas yang di berikan oleh guru, bahkan siswa terkadang merasa mengantuk ketika di kelas. Hal tersebut dialami oleh peneliti ketika guru kelas $\mathrm{V}$ menanyakan pekerjaan rumah, ada beberapa siswa yang tidak mengerjakan. Dan saat diberikan tugas, mereka tidak mau mengerjakan dengan alasan pusing. Hal tersebut serupa dengan sebuah kasus yang dari New York Times yaitu seorang anak yang mengalami kecanduan iPad. Anak tersebut terus meminta gadget nya ketika gadget tersebut tidak berada dalam genggaman tangannya. Anak tersebut dikatakan telah ketergantungan terhadap gadget. Anak tersebut tidak dapat terlepas dari gadget, bahkan saat makan, belajar, bermain, begitu pula saat tidur (Ameliola\&Nugraha, 2013:364 ).

Waktu belajar siswa tersita dengan adanya gadget yang mereka miliki. Tidak hanya dirumah, disekolah siswa juga bermain gadget bersama temannya setelah pulang sekolah hingga lupa waktu dan sering pulang terlambat.
Prestasi belajar yang dicapai oleh siswa terkait dengan kemampuan siswa dalam menangkap isi dan pesan dari kegiatan belajar yang dilakukannya. Kemampuan individu yang digunakan untuk menangkap isi dan pesan materi pelajaran terdiri atas tiga ranah, yaitu kognitif, afektif dan psikomotor. Kemampuan dalam pemahaman, penerapan, analisis dan evaluasi merupakan ranah kognitif (pengetahuan). Sedangkan kemampuan yang mengutamakan emosi, perasaan, serta reaksi yang terdiri atas penerimaan, partisipasi, penilaian (penentuan sikap organisasi dan pola hidup termasuk kedalam ranah afektif (sikap). Berbeda dengan psikomotor, yaitu kemampuan dalam keterampilan jasmani yang terdiri atas persepsi, kesiapan, gerakan terbimbing, gerakan terbiasa, gerakan kompleks, penyesuaian pola gerakan dan kreatifitas (Sagala, 2004:12).

Berdasarkan paparan diatas, rumusan masalah pada penelitian ini yaitu: (1) Bagaimana intensitas pemanfaatan gadget oleh siswa kelas $\mathrm{V}$ SDN Se-Gugus VIII Kecamatan Blimbing Kota Malang; (2) Bagaimana prestasi belajar siswa kelas V SDN SeGugus VIII Kecamatan Blimbing Kota Malang; (3) Adakah hubungan antara intensitas pemanfaatan gadget dengan prestasi belajar siswa kelas V SDN SeGugus VIII Kecamatan Blimbing Kota Malang. Penelitian ini bertujuan untuk mengetahui ada tidaknya hubungan antara intensitas pemanfaatan gadget dengan prestasi belajar siswa kelas $\mathrm{V}$ SDN Se-Gugus V Kecamatan Blimbing Kota Malang.

\section{Pengertian Intensitas \\ Pemanfaatan Gadget}

Intensitas merupakan kadar keseringan seorang siswa dalam melakukan suatu hal. Dalam penelitian ini intensitas pemanfaatan gadget merupakan kadar keseringan siswa dalam penggunaan gadget untuk berbagai macam fungsi dan tujuan. 


\section{Manfaat Gadget}

Datangnya teknologi komunikasi baru, ditandai dengan meningkatnya jumlah dan berbagai macam teknologi yang berbasis pada teknologi elektronika. Dan yang lebih penting adalah alam bagaimana media baru tersebut berfungsi, terjadi pertukaran informasi. Alam interaktif mungkin dibuat oleh elemen komputer yang terhubung menjadi jaringan dan didukung peralatan seperti satelit.

Gagdet merupakan alat elektronik yang digunakan sebagai media informasi, media belajar dan sebagai hiburan. Manfaat gadget lainnya yaitu dapat tersambung dengan internet. Siswa sekolah dasar sudah mengenal fungsi internet. Sehingga banyak siswa sekolah dasar yang menyalahgunakan penggunaan internet untuk hal negatif. Sehingga siswa harus selalu dalam pengawasan orang tua. Orang tua memberikan gadget pada anaknya dengan tujuan untuk mengenalkan games pada anaknya. Dibanding dnegan orang dewasa yang baru mengenal gadget, anak lebih cepat menguasasi gadget dari pada orang dewasa. Bahkan orang tua mereka belum tentu dapat mengoperasikan gadget yang mereka miliki (Warisyah, 2015:131).

Gadget dapat berpengaruh positif dan negatif terhadap prestasi belajar siswa. Prestasi belajar merupakan penguasaan pengetahuan atau keterampilan yang dikembangkan oleh mata pelajaran, yang ditunjukkan dengan nilai tes atau angka yang diberikan oleh guru.(Moeliono,1990:700). Apabila kegiatan belajar siswa terganggu dengan terlalu banyak bermain gadget maka akan berakibat pada penurunan prestasi belajar siswa. Namun apabila siswa menggunakan gadget untuk menambah ilmu pengetahuan disekolah dan tidak melupakan kewajiban seorang siswa untuk belajar, maka tidak akan berakibat pada menurunnya prestasi belajar.
Dikatakan berakibat pada prestasi belajarnya karena, penggunaan gadget terlalu berlebihan dapat menyebabkan kerusakan pada mata siswa. Sehingga akan menghambat siswa dalam belajar.

IPTEK berkembang pesat dan dapat mengubah kehidupan manusia kearah kebaikan, namun IPTEK tidak selalu memberikan penjelasan mengenai segala sesuatu yang berkaitan dengan kehidupan (Tilaar,1997:109). Siswa begitu menginginkan gadget karena mereka dapat dengan mudah mencari informasi yang mereka ingin ketahui. Berdasarkan pengamatan terhadap beberapa anak yang mengunjungi warung internet (warnet) beberapa siswa terlihat mengunjungi warnet dengan tujuan untuk mengerjakan tugas. Namun seiring dengan perkembangan jaman, siswa dapat mengakses internet melalui gadget yang mereka miliki. Internet tidak hanya memiliki sejumlah kelebihan, namun terdapat beberapa kelemahan, yaitu ketika siswa mencari informasi untuk pembelajaran ada beberapa hal yang perlu diperhatikan, diantaranya yaitu: (a) tersedia banyak informasi untuk pembelajaran, namun tidak semuanya dapat di ambil dan di butuhkan oleh siswa; (b) internet bersifat interaktid dengan tersedianya berbagai link menuju situs yang membut siswa tergoda untuk mengkliknya yang justru membuat pencarian informasi terbengkalai dan lepas kendali. (Penayus dalam Hudaya,2012).

\section{Dampak Pemanfaatan Gadget}

Teknologi gadget yang memiliki beragam manfaat dan kelebihan juga dapat mengakibatkan dampak positif dan negative bagi pengguna. Dampak positif dari penggunaan gadget yaitu akan lebih efisien dalam penggunaan waktu dalam berkomunikasi (Mubashiroh,2013). Dampak bagi siswa yaitu siswa menjadi lebih maju dalam mengikuti perkembangan jaman. Siswa menjadi lebih mudah menyesuaikan 
perkembangan jaman disbanding orang dewasa. Siswa akan lebih kreatif dalam memanfaatkan gadget yang mereka miliki apabila dengan pengawasan orang tua. Hampir semua mata pelajaran memiliki perangkat lunak untuk membantu proses pengajarannya. Mulai dari berbentuk $\mathrm{CD}$, tersedia di internet yang berupa portal belajar, ensiklopedia, game education dan sebagainya (Akbar,2006:168). Orang tua menganggap bahwa gadget merupakan salah satu alat yang dapat digunakan untuk mendidik anak, sehingga bukan menjadi hal yang aneh lagi apabila anak mendapat fasilitas gadgetdari orang tuanya,

Gadget dapat digunakan oleh siapa saja dan untuk apa saja tergantung dari kebutuhan pemilik gadget tersebut. Pemakaian gadget pada sekarang ini sudah digunakan mulai dari anak usia dini hingga orang dewasa. Syahra (2006) menyatakan bahwa semakin berkembangnya zaman tidak bisa dipungkiri bahwa perkembangan teknologi informasi dan komunikasi berlangsung semakin pesat dan penggunaannya telah menjangkau ke berbagai lapisan kehidupan masyarakat dari segala bidang, usia dan tingkat pendidikan. Penggunaan oleh orang dewasa, biasa digunakan untuk alat komunikasi, mencari informasi atau browsing, youtube, bermain game, ataupun lainnya. Sedangkan pemakaian pada anak usia dini biasanya terbatas dan penggunaannya hanya sebagai, media pembelajaran, bermain game, dan menonton animasi. Pemakaiannya pun dapat memiliki waktu yang beragam dan berbeda durasi serta intensitas pemakaiannya pada orang dewasa dan anak - anak.

Dampak positif penggunaan gadget: (1) berkembangnya imajinasi, (melihat gambar kemudian menggambarnya sesuai imajinasinya yang melatih daya pikir tanpa dibatasi oleh kenyataan); (2) melatih kecerdasan, (dalam hal ini anak dapat terbiasa dengan tulisan, angka, gambar yang membantu melatih proses belajar); (3) meningkatkan rasa percaya diri. (saat anak memenangkan suatu permainan akan termotovasi untuk menyelesaikan permainan); (4) mengembangkan kemampuan dalam membaca, matematika, dan pemecahan masalah. (dalam hal ini anak akan timbul sifat dasar rasa ingin tahu akan suatu hal yang membuat anak akan muncul kesadaran kebutuhan belajar dengan sendirinya tanpa perlu dipaksa).

Dampak negatif dari gadget adalah: (1) penurunan konsentrasi saat belajar (pada saat belajar anak menjadi tidak fokus dan hanya teringat dengan gadget, misalnya anak teringat dengan permainan gadget seolah-olah dia seperti tokoh dalam game tersebut); (2) malas menulis dan membaca, (hal ini diakibatkan dari penggunaan gadget misalnya pada saat anak membuka vidio di aplikasi Youtube anak cenderung melihat gambarnya saja tanpa harus menulis apa yang mereka cari); (3) penurunan dalam kemampuan bersosialisasi, (misalnya anak kurang bermain dengan teman dilingkungan sekitarnya, tidak memperdulikan keadaan disekelilingnya.); (4) kecanduan, (anak akan sulit dan akan ketergantungan dengan gadget karena sudah menajadi suatu hal yang menjadi kebutuhan untuknya); (5) dapat menimbulkan gangguan kesehatan, (jelas dapat menimbulkan ganggunan kesehatan karena paparan radisasi yang ada pada gadget, dan juga dapat merusak kesehatan mata anak); (6) perkembangan kognitif anak usia dini terhambat, (kognitif atau pemikiran proses psikologis yang berkaitan bagaimana individu mempelajari, memperhatikan, mengamati, membayangkan, memperkirakan, menilai dan memikirkan lingkungannya akan terhambat); (7) menghambat kemampuan berbahasa, (anak yang terbiasa menggunakan 
gadget akan cendrung diam, sering menirukan bahasa yang didengar, menutup diri dan enggan berkomunikasi dengan teman atau lingkungannya); (8) dapat mempengaruhi perilaku anak usia dini, (seperti contoh anak bermain game yang memiliki unsur kekerasan yang akan mempengaruhi pola perilaku dan karakter yang dapat menimbulkan tindak kekerasan terhadap teman).

\section{Peran Orang Tua Terhadap Pemanfaatan Gadget}

Dalam menggunakan gadget, siswa seharusnya di damping oleh orang dewasa. Karena siswa terkadang salah dalam menggunakan teknologi tersebut (Mubashiroh,2013). Selain itu orang tua berperan untuk membatasi penggunaan gadget. Karena radiasi gelombang elektromagnetik dari gadget dapat mengganggu penglihatan siswa. Serta orang tua melakukan seleksi terhadap aplikasi yang terdapat dalam gadget untuk mencegah adanya informasi yang negatif dari aplikasi tersebut.

\section{Prestasi Belajar}

Prestasi belajar merupakan kemampuan siswa dalam memahami materi, mengerjakan tugas saat belajar disekolah yang diberikan guru. Prestasi belajar adalah "penguasaan pengetahuan atau keterampilan yang dikembangkan oleh mata pelajaran, yang ditunjukkan dengan nilai tes atau angka nilai yang diberikan oleh guru (Moeliono,1990:700).

Dalam penelitian ini prestasi belajar siswa di ambil dari nilai asli salah satu mata pelajaran siswa. Fungsi dari prestasi belajar yang diperoleh siswa disekolah diantaranya yaitu: (a) prestasi sebagai indicator kualitas dan kuantitas pengetahuan yang telah dikuasai oleh siswa; (b) sebagai pemuas rasa ingin tahu kemampuan yang dimiliki; (c) sebagai bahan informasi dalam pendidikan; (d) sebagai indicator bagi suatu instansi pendidikan; (e) dapat dijadikan indicator terhadap daya serap siswa (Arifin dalam Herwin, 2015:18)

\section{METODE PENELITIAN}

Penelitian ini dilakukan pada bulan Maret hingga April Tahun 2016 di SDN Se-Gugus VIII Kecamatan Blimbing Kota Malang. Penelitian ini menggunakan pendekatan Kuantitatif dengan rancangan Korelasional noneksperimen. yang menjadi objek penelitian yaitu variabel bebas (variabel independent) intensitas pemanfaatan gadget $(\mathrm{X})$ dan variabel terikat (variabel dependent) prestasi belajar siswa (Y). Populasi dalam penelitian ini terdiri atas siswa kelas V SDN Se-Gugus VIII Kecamatan Bimbing Kota Malang dengan jumlah 8 kelas yang terdiri dari 286 siswa. Sampel dalam penelitian ini menggunaka teknik sampling jenuh, dengan menggunakan seluruh populasi, namun ada 71 siswa yang digunakan untuk uji validitas. Uji validitas dilakukan di 2 sekolah yang memiliki kelas paralel. Siswa yang digunaka untuk uji validitas yaitu siswa kelas $\mathrm{V}$ cemerlang SDN Pandanwangi 1 dan Siswa Kelas 5 SDN Pandanwangi 3. Namun hanya diambil 40 data untuk dilakukan uji validitas. Jadi sampel yang digunakan sebesar 215 responden siswa kelas V.

Instrumen yang digunakan yaitu berupa angket terbuka untuk mencari data intensitas pemanfaatan gadget. Angket intensitas pemanfaatan gadget terdiri dari 36 butir soal untuk uji validasi, dan diketahui 20 soal telah dinyatakan valid dan reliabel. Sedangkan dokumentasi digunakan untuk mencari data prestasi belajar siswa. Prestasi belajar siswa di ambil dari salah satu nilai mjatan mata pelajaran Ilmu Pengetahuan Alam pada Tema 6 Kurikulum 2016. Teknik pengumpulan data menggunakan metode kuisioner dan metode dokumentasi. Teknik analisis 
terdiri dari analisis deskriptif, uji normalitas, uji homogenitas, dan analisis korelasi Product Moment Pearson.

\section{HASIL DAN PEMBAHASAN

Deskripsi Intensitas Pemanfaatan
Gadget

Penyebaran angket di SDN Pandanwangi 2 pada kelas $\mathrm{V}$ dengan jumlah 37 siswa, di SDN Pandanwangi 3 kelas V terdiri dari 45 siswa, di SDN Pandanwangi 4 pada kelas $\mathrm{V}$ terdiri dari 39 siswa dan di SDN Pandanwangi 5 kelas V terdiri dari 39 siswa. Jadi responden dalam penelitian ini yaitu 215 siswa kelas V. Diketahui bahwa skor tertinggi yang diperoleh siswa dari hasil penyebaran angket tersebut yaitu 68 dan skor terendah yaitu 29 .

Diketahui bahwa siswa yang tingkat intensitasnya berada pada kategori tinggi berjumlah 34 siswa atau sebesar $16 \%$. Siswa yang tingkat intensitas pemanfaatan gadgetnya berada pada kategori sedang berjumlah 144 siswa atau sebesar $67 \%$. Sedangkan siswa yang tingkat intensitas pemanfaatan gadgetnya berada pada kategori rendah berjumlah 37 siswa atau sebesar $17 \%$. Berdasarkan hasil perhitungan rata-rata yang diperoleh variabel intensitas pemanfaatan gadget (variabel $\mathrm{X}$ ) yaitu sebesar 48,7395. Jika rata-rata jawaban responden menunjukkan angka 48,7395 responden berada pada interval 41-56 berati responden pada variabel intensitas pemanfaatan gadget (variabel $\mathrm{X}$ ) secara umum berada pada intensitas "sedang" terhadap pemanfaatan gadget.

\section{Deskripsi Prestasi Belajar Siswa}

Diketahui bahwa nilai tertinggi yang diperoleh siswa dari dokumentasi hasil belaajr siswa kelas V, yaitu 90 dan nilai terendah yang diperoleh, yaitu 65 . Berdasarkan distribusi nilai siswa kelas V SDN Se-gugus VIII Kecamatan Blimbing Kota Malang, diketahui bahwa siswa yang mendapat nilai 65-66 sebanyak 5 siswa (sebesar 2\%), siswa yang mendapat nilai 67 - 68 sebanyak 5 siswa (sebesar $2 \%$ ), siswa yang mendapat nilai $69-70$ sebanyak 13 siswa (sebesar 6\%), siswa yang mendapat nila 71-72 sebanyak 17 siswa (sebesar 8\%), siswa yang mendapat nilai 73-74 sebanyak 19 siswa (sebesar 9\%), siswa yang mendapat nilai 75-76 sebanyak 26 siswa (12\%), siswa yang mendapat nilai 77-78 sebanyak 33 siswa $(15 \%)$, siswa yang mendapat nilai $79-80$ sebanyak 26 (sebesar 12\%), siswa yang mendapat nilai 81-82 sebanyak 23 siswa $(11 \%)$, siswa yang mendapat nilai $83-84$ sebanyak 17 siswa (sebesar 8\%), siswa yang mendapat nilai 85-86 sebanyak 14 siswa (sebesar 7\%), siswa yang mendapat nilai 87-88 sebanyak 9 siswa (sebesar $4 \%$ ), siswa yang mendapat nilai $89-90$ sebanyak 8 siswa (sebesar 4\%).

Siswa yang prestasi belajarnya pada kategori baik berjumlah 31 siswa atau sebesar $14 \%$, siswa yang prestasi belajarnya pada kategori cukup berjumlah 153 siswa atau sebesar $71 \%$, dan siswa yang prestasi belajar nya pada kategori kurang berjumlah 31 siswa atau sebesar $14 \%$. Hasil perhitungan rata-rata yang diperoleh variabel prestasi belajar siswa (variabel Y) yaitu sebesar 77,9860. Jika rata-rata prestasi jawaban siswa menunjukkan angka 77,9860 berada pada interval 72- 84, maka responden secara umum memiliki tigkat prestasi "cukup".

Hasil pengujian validitas item angket menunjukkan bahwa 20 item pernyataan memiliki nilai di atas 0,312 sebagai nilai batas suatu item kuesioner penelitian dikatakan valid atau dapat di gunakan. Dan item pernyataan yang tidak valid tersebut tidak dapat digunakan. Hasil uji reliabilitas didapatkan hasil pengujian 40 responden dengan nilai 0,763 dengan $r$ tabel yaitu $N=0,312$. Suatu kuesioner dikatakan reliabel apabila nilai alpha $>\mathrm{r}$ tabel pada tingkat signifikan $95 \%(\propto=0,05)$. Hasil uji reliabilitas instrumen menunjukkan 0,763>0,312, sehingga dapat disimpulkan bawa 20 item pernyataan yang mengukur variabel 
intensitas pemanfaatan gadget dikatakan reliabel sehingga dapat digunakan dalam pengujian hipotesis.

Berdasarkan hasil uji normalitas pada variabel intensitas pemanfaatan gadget diperoleh $r_{\text {hitung }} 0,200$ dan variabel prestasi belajar dengan $r_{\text {hitung }} 0,200$. Hasil pengujian tersebut $\mathrm{r}_{\text {hitung }}>\mathrm{r}_{\text {tabel }}$ dengan $\mathrm{N}=215, \mathrm{r}$ tabel $=0,133$ pada tingkat signifikan $95 \%(\propto=0,05)$. Pada tabel diatas Variabel X , 0,200>0,133 dan variabel Y 0,200>0,133, dan dapat disimpulkan bahwa kedua variabel tersebut berdistribusi normal. Hasil uji homogenitas dengan menggunakan SPSS 16.0 for Windows diketahui nilai signifikan variabel prestasi belajar (Y) berdasarkan variabel intensitas pemanfaatan gadget $(X)=0,325>0,05$, artinya data variabel prestasi belajar (Y) berdasarkan variabel intensitas pemanfaatan gadget (X) mempunyai varian yang sama.

Hasil uji korelasi Product Moment Pearson, didapatkan hasil indeks korelasi $r_{x y}=\quad-0,033$ dengan $\mathrm{N}=215$ dengan $\propto$ $=0,133$. Hal ini berarti ada korelasi antara variabel $\mathrm{X}$ dan variabel $\mathrm{Y}$ namun arah korelasi nya negatif. Dikatakan ada korelasi karena tingkat korelasi pada tingkatan sangat rendah. Harga korelasi tidak signifikan, karena $0,033<0,133$ atau $\mathrm{r}_{\text {hitung }}<\mathrm{t}_{\text {tabel. }}$. Hipotesis pada penelitian ini berbunyi $\mathrm{H}_{0}$ tidak ada hubungan antara intensitas pemanfaatan gadget dengan prestasi belajar siswa, $\mathrm{H}_{\mathrm{a}}$ ada hubungan antara intensitas pemanfaatan gadget. Berdasarkan hasil pengujian korelasi pada tabel di atas, maka dihasilkan signifikan sebesar 0,632. Jika dibandingkan dengan $\propto=0,05$, nilai signifikan lebih besar dari pada $\propto=0,05$ . Artinya $\mathrm{H}_{0}$ diterima dan Ha ditolak. Jadi kesimpulan berdasarkan uji korelasi dan uj hipotesis, yaitu ada hubungan negatif yang tidak signifikan antara variabel intensitas pemanfaatan gadget dengan prestasi belajar siswa yang berarti semakin tinggi intensitas pemanfaatan gadget, maka prestasi siswa semakin menurun.

Berdasarkan hasil analisis deskripsi data intensitas pemanfaatan gadget, yang telah dilakukan oleh peneliti, diketahui bahwa 215 siswa yang memiliki intensitas pemanfaatan gadget dengan kategori tinggi sebanyak 34 siswa atau sebesar $34 \%$, siswa yang memiliki intensitas pemanfaatan gadget dengan kategori sedang yaitu sebanyak 144 siswa atau sebesar $67 \%$, sedangkan siswa yang memiliki intensitas pemanfaatan gadget dengan kategori rendah yaitu sebanyak 37 siswa atau sebesar 17\%. Dari paparan data diatas, dapat disimpulkan bahwa siswa kelas V SDN Se-Gugus Kecamatan Blimbing Kota Malang memiliki intensitas pemanfaatan gadget pada kategori sedang. Hal tersebut menunjukkan bahwa tidak semua siswa pada setiap sekolah selalu menggunakan gadget untuk hal positif seperti yang berhubungan dengan pelajaran disekolah.

Intensitas pemafaatan gadget merupakan, sebarapa sering siswa dalam menggunakan atau dalam memanfaatkan gadget. Pemanfaatan gadget oleh siswa yaitu sebagai hiburan, sebagai alat komunikasi dan siswa dapat menggunakan internet untuk mencari tugas rumah, berita, dan informasi lainnya, serta untuk mengakses sosial media yang dimiliki oleh siswa. Namun tidak semua siswa menggunakan gadget untuk hiburan. siswa dapat menggunakan gagdet untuk mencari materi nya disekolah, atau untuk mencari tugas yang diberikan guru.

Sebagian besar siswa memiliki berbagai sosial media. Dari sosial media tersebut siswa dapat berkomunikasi dengan teman-temannya untuk membicaran pelajaran disekolah. Namun pada hasil analisis data intensitas pemanfaatan gadget, tidak ada siswa yang menggunakan gadget hanya untuk belajar, mereka memiliki berbagai aplikasi yang menarik pada gadget yang dimilikinya. Pada hasil penelitian ini, 
tidak banyak siswa yang selalu mendapatkan peringkat 10 besar di kelasnya, dari data angket yang telah disebar ke 215 responden, hanya ada 28 siswa yang menjawab selalu mendapatkan peringkant 10 besar disekolah, 32 siswa menjawab sering, 63 siswa yang menjawab kadang-kadang, dan 92 siswa menjawab tidak pernah.

Sebagian besar siswa memiliki berbagai sosial media. Dari sosial media tersebut siswa dapat berkomunikasi dengan teman-temannya untuk membicaran pelajaran disekolah. Namun pada hasil analisis data intensitas pemanfaatan gadget, tidak ada siswa yang menggunakan gadget hanya untuk belajar, mereka memiliki berbagai aplikasi yang menarik pada gadget yang dimilikinya. Pada hasil penelitian ini, tidak banyak siswa yang selalu mendapatkan peringkat 10 besar di kelasnya, dari data angket yang telah disebar ke 215 responden, hanya ada 28 siswa yang menjawab selalu mendapatkan peringkant 10 besar disekolah, 32 siswa menjawab sering, 63 siswa yang menjawab kadang-kadang, dan 92 siswa menjawab tidak pernah.

Prestasi belajar merupakan kemampuan siswa dalam memahami materi pelajaran yang dituangkan dalam bentuk nilai. Pada penelitian ini prestasi belajar siswa yang digunakan yaitu nilai harian siswa pada salah satu muatan mata pelajaran tema 6 Kurikulum 2013 semester II. Nilai harian yang diberikan oleh guru, dijadikan dokumen oleh peneliti. Berikut hasil analisis data prestasi siswa yaitu, siswa dengan yang memiliki tingkat prestasi belajar dengan kategori baik sebanyak 31 siswa atau sebesar 14\%, siswa yang memiliki tingkat prestasi belajar dengan kategori cukup sebanyak 153 siswa atau sebesar $71 \%$, dan siswa yang memiliki prestasi belajar dengan kategori kurang sebanyak 31 siswa atau sebesar $14 \%$.

\section{SIMPULAN}

Berdasarkan pada rumusan masalah, hasil analisis dan pembahasan dapat disimpulkan bahwa, intensitas pemanfaatan gadget tergolong pada kategori sedang dengan presentase $67 \%$ yaitu sebanyak 144 siswa. Hasil penelitian pada variabel prestasi belajar secara umum siswa kelas V SDN SeGugus VIII Kecamatan Blimbing Kota Malang tergolong pada kategori cukup. Hasil analisis uji korelasi menunjukkan hubungan negatif yang sangat rendah dan tidak signifikan. Hipotesis menyatakan ada hubungan negatif yang tidak signifikan antara intensitas pemanfaatan gadget dengan prestasi belajar siswa kelas V SDN Se-gugus VIII Kecamatan Blimbing Kota Malang diterima. Intensitas pemanfaatan gadget tidak berpengaruh pada prestasi belajar siswa. Namun jika dilihat dari tanda negatif pada $\mathbf{r}_{\text {hitung }}$, jika semakin tinggi intensitas pemanfaatan gadget maka prestasi siswa dapat menurun.

Berdasarkan kesimpulan hasil penelitian diatas, maka saran dan rekomendasi yang diajukan dirumuskan sebagai berikut. Di sarankan bagi sekolah agar memberikan batasan kepada siswa dalam hal intensitas dan pemanfaatan gadget, disarankan bagi jurusan Kependidikan Sekolah Dasar dan Prasekolah agar hasil penelitian ini dapat dijadikan referensi bagi jurusan KSDP program studi S1-PGSD untuk meningkatkan kompetensi mahasiswa dalam memahami hubungan intensitas pemanfaatan gadget dengan prestasi belajar. Di sarankan bagi Mahasiswa dan peneliti lain agar dapat di digunakan sebagai sumber inspirasi di bidang yang sejenis. Kelemahan atau keterbatasan penelitian ini yaitu dilakukan dalam lingkup kecil atau hanya dalam satu gugus saja. Disarankan untuk peneliti lain agar dapat melanjutkan untuk mencoba penelitian sejenis namun dengan skala yang lebih luas dan dapat melakukan penyempurnaan pada 
indikator-indikator untuk dikembangkan pada instrumen penelitian serta melakukan penelitian sejenis dengan permasalahan yang belum terungkap melalui variabel lain.

\section{DAFTAR PUSTAKA}

Akbar. 2006. Panduan Cepat Menguasai Teknologi Informasi dan Komunikasi. Yogyakarta: Penerbit Gava Media

Ameliola \& Nugraha. 2013.

Perkembangan Media Informasi

Dan Teknologi Terhdapa Anak dalam Era Globalisasi . Disajikan dalam Prosiding The $5^{\text {th }}$

International Conference on Indonesian Studies: "Ethnicity and Globalization", Fakultas Pertanian Universitas Brawijaya Malang (Online), (https://icssis.files.wordpress.com /2013/09/2013-02-29.pdf ), diakses pada 18 Februari 2016.

Herwin.2015. Hubungan Tentang Intensitas Pendampingan belajar dari Orang tua Dengan Prestasi Belajarnya Kelas IV di SDN SeGugus I Desa Depok Kecamatan Panggul Trenggalek. Malang: Universitas Negeri malang

Hudaya,Atung,Tri . 2012. Pola

Penggunaan Dan Hubungan Antara Intensitas Penggunaan Intenet Sebagai Sumber Belajar Dan Prestasi Belajar Mahasiswa Teknik Sipil Universitas Negeri Malang. Malang. Universitas Negeri Malang

Manumpil, dkk. 2012. Hubungan Penggunaan Gadget Dengan Tingkat Prestasi Sisw Di SMA Negeri 9 manado (Online), ejournal keperawatan(e-Kep) Volume 3 Nomor 2 April 2015, (http://download.portalgaruda.org /article.php?article $=316368 \& \mathrm{val}=$ $5798 \&$ title $=$ HUBUNGAN\% $20 \mathrm{PE}$ NGGUNAAN\%20GADGET\%20 DENGAN\%20TINGKAT\%20PR ESTASI\%20SISWA\%20DI\%20S MA\%20NEGERI\%209\%20MAN ADO ), diakses pada 23 Desember 2015

Moeliono,dkk. 1990. Kamus Besar Bahasa Indonesia. Jakarta: Balai Pustaka

Mubashiroh. 2013. Gadget, Penggunaan dan Dampak pada AnakAnak(Online), (http://jurnalilmiahtp.blogspot.co. $\mathrm{id} / 2013 / 11 /$ gadget-penggunaandan-dampak-pada-anak.html ), Semarang : Universitas Negeri Semarang, diakses pada 23 Desember 2016

Nikmah, Astin. 2013. Dampak Penggunaan Hand Phone Terhadap Prestasi Siswa. EJurnal Dinas Pendidikan Kota Surabaya;Volume 5 (online), (http://dispendik.surabaya.go.id/s urabayabelajar/jurnal/199/5.7.pdf ) diakses pada 6 Januari 2016

Orange dan O'Flynn. 2007. The Media Diet for Kids. Jakarta: PT Serambi Ilmu Semesta.

Sagala, syaiful. 2004. Konsep \& makna pembelajaran. Bandung : alfabeta

Syahra, R. 2006. Informatika Sosial Peluang dan Tantangan. Bandung: LIPI.

Tilaar,H.A.R. 1997. Pengembangan Sumber Daya Manusia Dalam Era Globalisasi. Jakarta: PT Grasindo

Warisyah,Yusmi.2015. Pentingnya "Pendampingan Dialogis" Orang 
Tua Dalam Penggunaan Gadget Pada Anak Usia Dini. Makalah disajikan dalam Prosiding Seminar Nasional Pendidikan di FKIP Universitas Muhammadiyah Ponorogo, 7 November 2015 (online), (http://semnas.fkip.umpo.ac.id/wp -content/uploads/2015/12/014-

Yusmi-W.pdf ), diakses 18

februari 2016 